\title{
A predicted protein, KIAA0247, is a cell cycle modulator in colorectal cancer cells under 5-FU treatment
}

\author{
Chi-Jung Huang 1,2,3, Shung-Haur Yang ${ }^{4}$, Shih-Ming Huang ${ }^{2}$, Chih-Ming Lin ${ }^{1,5}$, Chih-Cheng Chien ${ }^{1,6}$, Yan-Chu Chen ${ }^{2}$, \\ Chia-Long Lee ${ }^{7}$, Hao-Han Wu $\mathrm{Wu}^{4}$ and Chun-Chao Chang ${ }^{8^{*}}$
}

\begin{abstract}
Background: Colorectal cancer $(C R C)$ is the predominant gastrointestinal malignancy and the leading cause of cancer death. The identification of genes related to CRC is important for the development of successful therapies and earlier diagnosis.

Methods: Molecular analysis of feces was evaluated as a potential method for CRC detection. Expression of a predicted protein with unknown function, KIAA0247, was found in feces evaluated using specific quantitative realtime polymerase chain reaction. Its cellular function was then analyzed using immunofluorescent staining and the changes in the cell cycle in response to 5-fluorouracil (5-FU) were assessed.

Results: Gastrointestinal tissues and peripheral blood lymphocytes ubiquitously expressed KIAA0247. 56 CRC patients fell into two group categories according to fecal KIAA0247 mRNA expression levels. The group with higher fecal KIAA0247 ( $n=22 ; \geq 0.4897)$ had a significantly greater five-year overall survival rate than the group with lower fecal KIAA0247 ( $n=30 ;<0.4897)(66.0 \pm 11.6 \% ; p=0.035$, log-rank test). Fecal expression of KIAA0247 inversely related to $C R C$ tumor size (Kendall's tau- $b=-0.202 ; p=0.047$ ). Immunofluorescent staining revealed that the cytoplasm of CRC cells evenly expresses KIAA0247 without 5-FU treatment, and KIAA0247 accumulates in the nucleus after $40 \mu \mathrm{M}$ 5-FU treatment. In HCT116 p53-- cells, which lack p53 cell cycle control, the proportion of cells in the G2/M phase was larger (13\%) in KIAA0247-silent cells than in the respective shLuc control (10\%) and KIAA0247-overexpressing cells (7\%) after the addition of low dose $(40 \mu \mathrm{M}) 5$-FU. Expression of three cyclin genes (cyclin A2, cyclin B1, and cyclin B2) also downregulated in the cells overexpressing KIAA0247.

Conclusions: This is the first description of a linkage between KIAA0247 and CRC. The study's data demonstrate overexpression of KIAA0247 associates with 5-FU therapeutic benefits, and also identify the clinical significance of fecal KIAA0247 in CRC.
\end{abstract}

\section{Background}

Colorectal cancer (CRC) is the predominant gastrointestinal malignancy and the leading cause of cancer death [1]. CRC usually arises as a consequence of the accumulation of genetic and epigenetic alterations in colonic epithelial cells during neoplastic transformation [2]. The identification of CRC-related genes is important

\footnotetext{
* Correspondence: chunchao@tmu.edu.tw

${ }^{8}$ Division of Gastroenterology and Hepatology, Department of Internal Medicine, Taipei Medical University Hospital and Department of Internal Medicine, School of Medicine, College of Medicine, Taipei Medical University, Taipei 11031, Taiwan

Full list of author information is available at the end of the article
}

for the development of successful therapies and earlier diagnosis [3-5].

Genes involved in cell growth, cell cycle, apoptosis, angiogenesis, or invasion could have a crucial role in CRC tumorigenesis [6,7]. In particular, some promising targets responsible for the control of cell cycle progression have attracted a great deal of attention for drug discovery $[8,9]$. In recent decades, researchers developed several agents with the function of regulating the degree of cell cycle arrest for cancer treatment $[10,11]$. Enhancement of the effects of defects in the G2/M arrest checkpoint that make a damaged cell enter

\section{Biomed Central}

(c) 2011 Huang et al; licensee BioMed Central Ltd. This is an Open Access article distributed under the terms of the Creative Commons Attribution License (http://creativecommons.org/licenses/by/2.0), which permits unrestricted use, distribution, and reproduction in any medium, provided the original work is properly cited. 
mitosis and undergo apoptosis might increase the effective cytotoxicity of chemotherapy [8].

The novel gene, KIAA0247, previously identified as one of the CRC-related candidates, is a speculated target of the tumor suppressor gene, p53, because of a p53-responsive element in the promoter region $[12,13]$. This implies that KIAA0247 might participate in the p53 pathway of CRC tumorigenesis. Previous studies have identified that many molecules have altered expression in the feces of CRC patients [14,15]; some of these novel candidate genes with unknown function. The detailed characteristics of KIAA0247 are still unknown. Further understanding of the cellular functions in CRC of this predicted protein may provide an alternative target for CRC treatment.

The present study, therefore, aimed to investigate the molecular function of KIAA0247 in CRC tumorigenesis. Firstly, the clinical significance of KIAA0247 was evaluated from fecal samples of CRC patients using specific quantitative real-time polymerase chain reaction (qRTPCR). Its cellular function was then evaluated using immunofluorescent staining and the changes in the cell cycle in response to 5-fluorouracil (5-FU) were assessed. Results demonstrated that, in CRC patients, the expression of KIAA0247 influences the effects of treatment with 5-FU at a relatively low concentration.

\section{Methods}

\section{Patients}

Solid fecal samples (approximately $0.5 \mathrm{~g}$ ) from 56 CRC patients from the Cathay General Hospital (CGH) or Taipei Veterans General Hospital were taken before surgery or any application of chemotherapy with Institutional Review Board (IRB)-approved informed consent at the CGH IRB. Follow-up data were obtained prospectively, and the mean follow-up time was 34.9 months (SD, 26.8; median, 23). The patients' initial tumor stage and other clinical information are listed in Table 1. Presence of distant metastasis was routinely confirmed by abdominal computed tomography.

\section{Colonic cell lines and human multiple tissue cDNA}

The p53-null HCT116 cell line (HCT116 p53/-, a gift from Prof. Bert Vogelstein) was cultured in Dulbecco's modified Eagles medium with $5 \mathrm{mM}$ glutamine according to routine culture procedures. The cDNAs of multiple gastrointestinal tissues and PBL for qRT-PCR were selected from the human multiple tissue cDNA panels (BD Biosciences Clontech, Mountain View, CA).

\section{Total RNA extraction and reverse transcription reaction}

Total RNA from these cultured cells was extracted using the Easy Pure Total RNA Mini Kit (Bioman, Taipei, Taiwan) according to the manufacturer's instructions and fecal RNA was prepared as reportedly previously [16].
Table 1 Analyses of mRNA levels of fecal KIAA0247 in clinical features

\begin{tabular}{|c|c|c|c|c|}
\hline \multicolumn{2}{|c|}{ Features $^{a}$} & \multirow[t]{2}{*}{$n^{\mathbf{b}}$} & \multirow{2}{*}{$\begin{array}{c}\text { Cases with higher } \\
\text { mRNA } \\
\text { levels of fecal } \\
\text { KIAA0247 } \\
(>0.4897)\end{array}$} & \multirow{2}{*}{$\begin{array}{c}p- \\
\text { value }\end{array}$} \\
\hline Age (years) & & & & \\
\hline & $\leq 66.0$ & 27 & 11 (40.7\%) & 0.874 \\
\hline & $>66.0$ & 28 & $12(42.9 \%)$ & \\
\hline \multicolumn{5}{|l|}{ Gender } \\
\hline & Male & 37 & $14(37.8 \%)$ & 0.290 \\
\hline & Female & 19 & $10(52.6 \%)$ & \\
\hline \multicolumn{5}{|l|}{ Dukes' stages } \\
\hline & $A+B$ & 28 & $14(50.0 \%)$ & 0.210 \\
\hline & $C+D$ & 27 & 9 (33.3\%) & \\
\hline \multicolumn{5}{|l|}{$\begin{array}{l}\text { Depth of } \\
\text { invasion }\end{array}$} \\
\hline & $\mathrm{T} 1+\mathrm{T} 2$ & 24 & $14(58.3 \%)$ & 0.053 \\
\hline & $\mathrm{T} 3+\mathrm{T} 4$ & 31 & $10(32.3 \%)$ & \\
\hline \multicolumn{5}{|l|}{$\begin{array}{l}\text { Lymphatic } \\
\text { invasion }\end{array}$} \\
\hline & NO & 32 & 15 (46.9\%) & 0.568 \\
\hline & $\mathrm{N} 1+\mathrm{N} 2+\mathrm{N} 3$ & 23 & 9 (39.1\%) & \\
\hline \multicolumn{5}{|l|}{$\begin{array}{c}\text { Distant } \\
\text { metastasis }\end{array}$} \\
\hline & No & 34 & 18 (52.9\%) & 0.058 \\
\hline & Yes & 22 & $6(27.3 \%)$ & \\
\hline \multicolumn{5}{|l|}{ Tumor location } \\
\hline & Right & 20 & $6(30.0 \%)$ & \\
\hline & Left & 13 & $6(46.2 \%)$ & 0.341 \\
\hline & Rectum & 19 & $10(52.6 \%)$ & \\
\hline \multicolumn{5}{|l|}{ CEA (ng/ml) } \\
\hline & $\leq 5$ & 28 & 15 (53.6\%) & 0.072 \\
\hline & $>5$ & 27 & 8 (29.6\%) & \\
\hline \multicolumn{5}{|l|}{ CA19-9 (U/ml) } \\
\hline & $<37$ & 34 & 15 (44.1\%) & 0.371 \\
\hline & $\geq 37$ & 19 & $6(31.6 \%)$ & \\
\hline \multicolumn{5}{|l|}{ Differentiation } \\
\hline & $\begin{array}{c}\text { Well/ } \\
\text { moderate }\end{array}$ & 47 & $22(46.8 \%)$ & 0.065 \\
\hline & Poor & 5 & $0(0 \%)$ & \\
\hline
\end{tabular}

${ }^{a}$ Median age, 66 years; age range, 40.3-89.5 years; CEA, carcinoembryonic antign; CA19-9, carbohydrate antigen 19-9.

${ }^{\mathrm{b}}$ Numbers of assessed cases are dependent on the available cases.

One microgram of cellular total RNA or fecal RNA was reverse transcribed to single-stranded cDNA using an oligo $(\mathrm{dT})_{12}$ primer with the ABI Reverse Transcriptase Kit (Applied Biosystems, Carlsbad, CA) according to the manufacturer's protocol. Synthesized cDNA could be used directly in the following qRT-PCR analyses.

\section{qRT-PCR}

The qRT-PCR for quantifying targets in multiple tissue cDNA, cellular cDNA, and fecal cDNA was performed 
using a TaqMan probe, from the Human Universal Probe Library (Roche Diagnostics, Mannheim, Germany), as described previously $[17,18]$ except for fecal KIAA0247 (NM014734). To quantify fecal KIAA0247, the amount of each primer was elevated to 4 pmol in a $10 \mu \mathrm{L}$ reaction volume. Each fecal sample run also included human reference cDNA (Clontech, Mountain View, CA) as a standard to estimate the relative expression levels in feces. The relative levels of expression of genes in various samples were determined by normalizing their expression to that of $18 \mathrm{~S}$ ribosomal (r)RNA (X03205) [19]. The primers and universal probes used to quantify KIAA0247, cyclin A2 (NM001237), cyclin B1 (NM031966), and cyclin B2 (NM004701) are listed in Table 2.

\section{Lentivirus-mediated RNA interference (RNAi) and overexpression of KIAA0247}

The lentiviral constructs encoding the siKIAA0247 hairpin (pLKO.1-KIAA0247: TRCN0000134410) for gene silencing (shKIAA0247) or the KIAA0247 cDNA for gene overexpression (overKIAA0247) were obtained from the National RNAi Core Facility located at the Institute of Molecular Biology/Genomic Research Center, Academia Sinica, Taiwan. pLKO.1-Luc (TRCN0000072246) acted as a control (shLuc) for the previously mentioned two lentiviruses. Infection of each lentivirus into colonic cells was performed as described previously. Changes in the expression of KIAA0247 were determined using qRT-PCR.

\section{Cell cycle analysis by flow cytometry}

To determine the cellular effects of KIAA0247 in colonic cells, cell cycle analysis was performed using flow cytometry by analyzing the DNA content [20] of propidium iodide (PI)-stained nuclei as described previously [21]. Colonic cells transfected with shKIAA0247, shLuc,

Table 2 Primers and TaqMan probes for qRT-PCR

\begin{tabular}{|c|c|c|c|}
\hline $\begin{array}{l}\text { Gene } \\
\text { name }\end{array}$ & Reference & Primer sequence $\left(5^{\prime} \text { to } 3^{\prime}\right)^{a}$ & $\begin{array}{c}\text { Probe } \\
\text { number }\end{array}$ \\
\hline \multirow[t]{2}{*}{ KIAA0247 } & NM014734 & F: CTGCAGATTCAGAGAACAGTGAC & 82 \\
\hline & & R: CTCATGCTTCTTTCAACAGTGG & \\
\hline \multirow{2}{*}{$\begin{array}{l}\text { Cyclin A2 } \\
\text { (CCNA2) }\end{array}$} & NM001237 & F: CCATACCTCAAGTATITGCCATC & 67 \\
\hline & & R: TCCAGTCTTTCGTATTAATGATTCAG & \\
\hline \multirow{2}{*}{$\begin{array}{l}\text { Cyclin B1 } \\
\text { (CCNB1) }\end{array}$} & NM031966 & F: CATGGTGCACTITCCTCCTT & 18 \\
\hline & & R: AGGTAATGTTGTAGAGTTGGTGTCC & \\
\hline \multirow{2}{*}{$\begin{array}{l}\text { Cyclin B2 } \\
\text { (CCNB2) }\end{array}$} & NM004701 & F: GCATTATCATCCTTCTAAGGTAGCA & 4 \\
\hline & & R: TGTAATACTGCTGCTTTAAGTTCCA & \\
\hline
\end{tabular}

${ }^{a} F$, forward primer; $R$, reverse primer.

${ }^{b}$ Probe number, from the Human Universal Probe Library of Roche Diagnostics, Mannheim, Germany. or overKIAA0247 were plated, at a density of $5 \times 10^{6}$ cells/well in 6-well dishes, and cultured for $24 \mathrm{~h}$. These subconfluent cells were incubated with DNA analogue 5-FU $(40 \mu \mathrm{M})$ (Sigma-Aldrich, St. Louis, MO) for another $24 \mathrm{~h}$. The control cells were treated with medium alone. Thereafter, cells were trypsinized, washed twice with PBS, and fixed in $70 \%$ ethanol for $5 \mathrm{~h}$ at $4^{\circ} \mathrm{C}$. These fixed cells were washed twice more with PBS, incubated with $1 \mu \mathrm{g} / \mathrm{ml}$ RNase A for $1 \mathrm{~h}$ at $37^{\circ} \mathrm{C}$, and stained with $5 \mu \mathrm{g} / \mathrm{ml}$ PI for $1 \mathrm{~h}$ at room temperature. The percentage of cells in the G0/G1 phase, S phase, and $\mathrm{G} 2 / \mathrm{M}$ phase were determined according to relative DNA content analyzed using a FACScan flow cytometer (Becton Dickinson, Franklin Lakes, NJ) [22].

\section{Immunodetection of KIAA0247}

To further evaluate the highly expressed KIAA0247, the colonic cells transfected with shLuc or overKIAA0247 cultured in 6-well dishes were fixed, permeabilized, and blocked for immunofluorescent staining as previously reported, with some essential modifications [17]. Cells were probed with diluted anti-KIAA0247 antibody (1:500; H00009766-B01P; Abnova, Taipei, Taiwan) for $16 \mathrm{~h}$ at $4^{\circ} \mathrm{C}$ followed by incubation with R-phycoerythrin-conjugated goat anti-rabbit antibody (1:200; 405307; BioLegend, San Diego, CA) for $1 \mathrm{~h}$ at room temperature. The cellular DNA was stained with 4",6" diamidino-2-phenylindole. The stained samples were then dehydrated, mounted, and analyzed using a Nikon Eclipse 80i fluorescence microscope (Nikon Instruments, Melville, NY).

\section{Statistical analysis}

Survival probabilities were estimated using the KaplanMeier method and compared using the log-rank test. Chi-squared or Fisher's exact tests were used for group comparisons. Kendall's tau-b correlation and linear regression analysis were applied to analyze correlations between the relative levels of fecal KIAA0247 and sizes of colonic tumor [23]. The Student's $t$ test was used to compare the mRNA levels of cyclins in different groups. These statistical analyses were performed using SPSS 13.0 software (SPSS, Chicago, IL). The Medcalc software statistical package was employed to generate receiveroperating characteristic (ROC) curves. A $p$ value $<0.05$ was considered statistically significant.

\section{Results}

Expression of KIAA0247 in multiple gastrointestinal tissues and colonic cell lines

qRT-PCR determined the expression of the uncharacterized gene, KIAA0247, in human gastrointestinal tissues and colonic cell lines. Results indicated that KIAA0247 ubiquitously expresses in gastrointestinal tissues and in 
peripheral blood leukocytes (PBL), with highest expression in PBL and lowest expression in the small intestine (Figure 1).

\section{Relationship of fecal KIAA0247 expression with clinical features of CRC patients}

Receiver-operating characteristic (ROC) curve analysis, based on relative KIAA0247 expression levels, stratified the 56 CRC patients into two groups to determine the clinical significance of fecal KIAA0247 expression. A cutoff at a fecal KIAA0247 expression level of 0.4897 provided a sensitivity of 0.77 (95\% CI, 0.55-0.92) and a specificity of 0.53 (95\% CI, 0.35-0.70) for predicting the prognosis of patients $(p=0.017)$. The area under the ROC curve for fecal KIAA0247 was 0.673 (95\% CI, 0.535-0.793) (Figure 2A). The group with higher fecal KIAA0247 expression (KIAA0247 ${ }^{+}, n=22$; $\geq 0.4897$ ) demonstrated a greater five-year overall survival rate than the group with lower fecal KIAA0247 expression (KIAA0247,$n=30 ;<0.4897)(66.0 \pm 11.6 \% ; p=0.035$, log-rank test) (Figure 2B). The Kendall's tau-b correlation test revealed an inverse relationship between fecal levels of KIAA0247 and the size of CRC tumors (Kendall's tau-b $=-0.202 ; p=0.047)$. Figure 3 shows this negative association, plotted according to linear regression (slope $=-0.286$ ), with almost statistical significance $(p=0.076)$. Table 3 also shows the association between fecal KIAA0247 and tumor size. A significantly higher percentage $(56.7 \%, 17$ of 30$)$ of patients with positive fecal KIAA0247 occurred in the group in which patients had a tumor size smaller than the mean value $(4.4 \mathrm{~cm})$ $(p=0.020)$. Although no significant differences were noted for other clinical features $(p>0.05)$, the patients with positive fecal KIAA0247 demonstrated a trend to be diagnosed at an earlier stage (AJCC Stage I; 56.5\%,

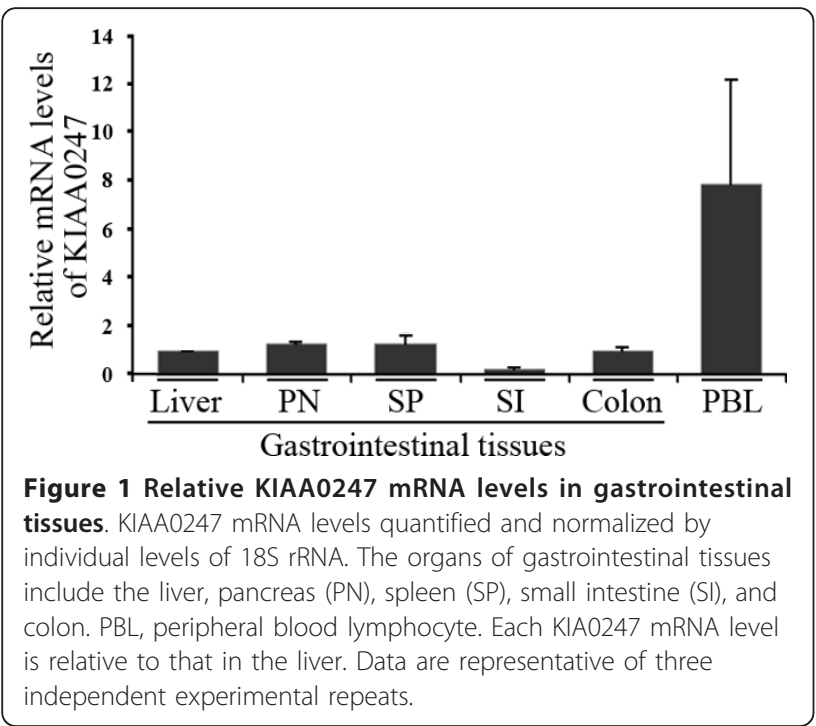

13 of $23 ; p=0.061$ ) and to have lower levels of serum carcinoembryonic antigen $(\leq 5 \mathrm{ng} / \mathrm{mL} ; 53.6 \%, 15$ of 28 ; $p=0.072$ ).

\section{Reduction in proportion of colonic cells in G2/M phase with increased KIAA0247 expression}

To exclude the influence of p53 on the cell cycle, a p53 knockdown CRC cell line (HCT116 p53-/-) revealed the cellular effects of KIAA0247 in the presence of 5-FU. DNA content staining determined the proportions of these colonic cells in G0/G1, S, and G2/M phases of the cell cycle. In these HCT116 p53 ${ }^{-/-}$cells, the proportion of cells in the G2/M phase was larger (13\%) in KIAA0247-silent cells than in the respective shLuc control (10\%) and KIAA0247-overexpressing cells (7\%) after the addition of a low dose $(40 \mu \mathrm{M})$ of 5 -FU (Figure 4 ). The KIAA0247-overexpressing cells showed only onethird (7\% vs. 21\%) as many cells in the G2/M fraction after treatment with $40 \mu \mathrm{M} 5$-FU.

To obtain a more comprehensive understanding of the ability of KIAA0247 to reduce the G2/M population, qRT-PCR quantified the mRNA levels of genes belonging to the highly conserved cyclin family. As shown in Figure 5, CRC cells that overexpressed KIAA0247 simultaneously downregulated the expression of three cyclin genes (cyclin A2, cyclin B1, and cyclin B2) after $40 \mu \mathrm{M}$ 5 -FU treatment. For example, the mRNA level of cyclin A2 in 5-FU-treated KIAA0247-overexpressing cells was $69 \%$ of that in these cells without 5-FU treatment. However, this cyclin A2 downregulation was not detected in the shLuc cells. Cyclin B1 and cyclin B2 mRNA levels demonstrated similar trends after the same treatment.

\section{Intracellular localization of KIAA0247 in colonic cells}

Immunofluorescent staining of overexpressed KIAA0247 in $\mathrm{HCT} 116 \mathrm{p} 53^{-/-}$cells identified that, under 5-FU-free conditions, the cytoplasm of CRC cells weakly expressed endogenous KIAA0247 (red fluorescence). This endogenous KIAA0247 demonstrated a tendency to move into the nucleus after treatment of cells with $40 \mu \mathrm{M}$ 5-FU (Figure 6A, indicated as white arrowhead). In the KIAA0247-overexpressing cells KIAA0247 clearly accumulated in the nucleus (Figure 6B, indicated as white arrowhead). KIAA0247 overexpressed in the cytoplasm of most CRC cells without 5-FU treatment and accumulated in the nucleus after cellular DNA damage by $40 \mu \mathrm{M} 5$-FU.

\section{Discussion}

Cell cycle checkpoints are important control mechanisms which ensure the proper passage of genetic codes and genome stability [24,25]. One of the checkpoints, the $\mathrm{G} 2 / \mathrm{M}$ checkpoint, blocks the entry into mitosis after DNA damage [26]. Many previous reports indicated that 

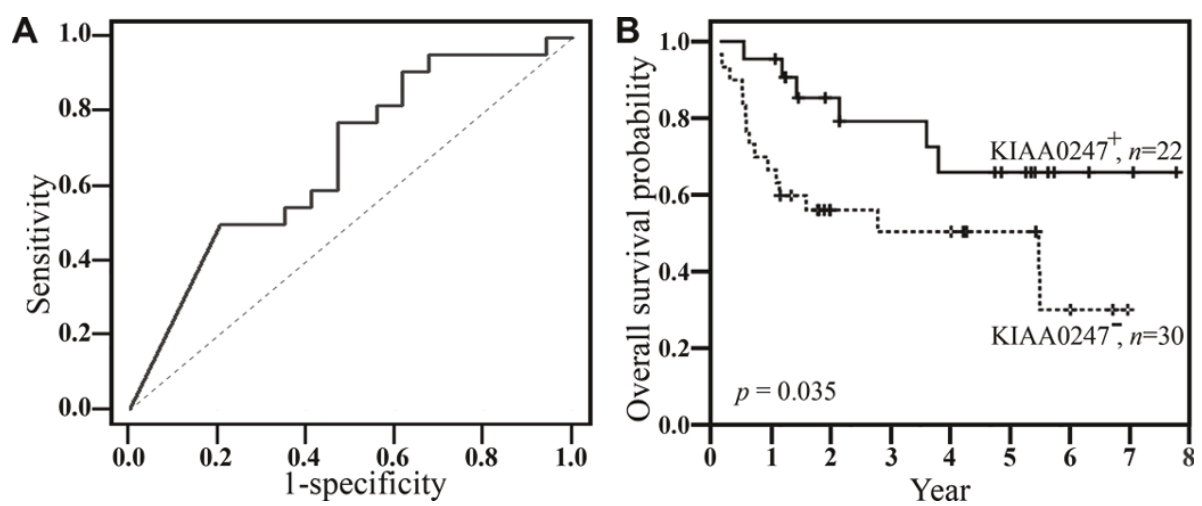

Figure 2 Overall survival of CRC patients according to fecal KIAA0247 mRNA levels. (A) Receiver operating characteristic curve for fecal KIAA0247 from CRC patients. (B) Overall survival of CRC patients. Survival probabilities estimated by the Kaplan-Meier method and compared using the log-rank test according to the fecal KIAA0247 mRNA levels in CRC patients. Patients are stratified into two groups: KIAA0247 (<0.4897, $n=30)$ and $\operatorname{KIAA0247}^{+}(\geq 0.4897, n=22) . p=0.035$, log-rank test.

p53 can regulate the $\mathrm{G} 2 / \mathrm{M}$ transition via induction of

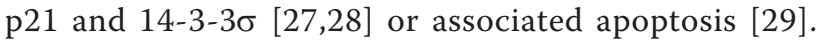
The findings of two investigations indicated that a p53independent control also coordinates activation of the G2/M checkpoint [30,31].

This study demonstrated that KIAA0247 is under p53independent control in CRC cells despite speculation that it is a p53-responsive target [12]. The predicted p53-responsive elements in the KIAA0247 promoter region demonstrated no electrophoretic mobility shift with p53 protein in a gel shift assay (data not shown). Higher expression of KIAA0247 occurred in fecal samples from early-stage CRC patients with a greater fiveyear overall survival rate. Use of a p53-null CRC cell line at Dukes' stage B, HCT116 $\mathrm{p} 53^{-/-}$, as a target cell,

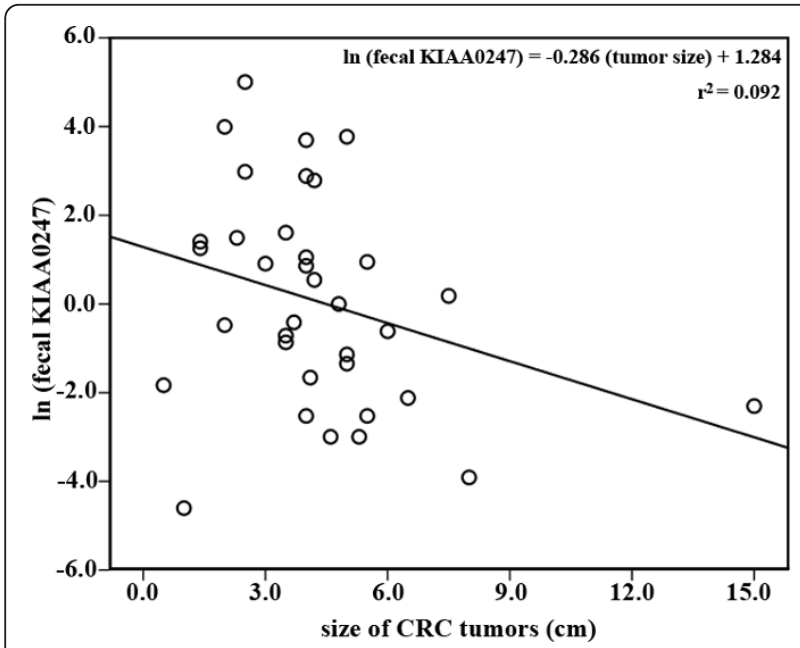

Figure 3 Correlation between KIAA0247 fecal expression and sizes of CRC tumors. The sizes of CRC tumors negatively associated with the natural logarithm of fecal KIAA0247 expression (slope $=-0.286, p=0.076$ ). excluded the influence of p53 on the cell cycle to correspond with the clinical findings.

Molecular markers are needed to assess CRC patients at Dukes' stage B who could benefit from adjuvant therapy [32]. Clinicians widely and routinely use 5-FU as one of the components in the therapeutic regimen $[33,34]$ and a cytotoxic effect occurs during the intracellular metabolism of 5-FU. Such adjuvant chemotherapy is also beneficial to patients at Dukes' stage C [35]. In the present study's findings with a CRC cell line at Dukes' stage B, $40 \mu \mathrm{M} 5$-FU decreased the number of cells in G2/M in the presence of KIAA0247 expression. The presence of KIAA0247 expression and 5-FU also negatively modulated three common cell cycle activators. These data emphasize that early-stage CRC cells that are able to overexpress KIAA0247 could impede the progression of the cell cycle at the G2/M phase if an appropriate amount of 5-FU damages the cellular DNA.

The DNA damage response activates in precancerous lesions to permit CRC progression [36]. As reviewed by Wei et al., the prevention of DNA instability and uracil misincorporation might reduce the risk of the early

Table 3 The association between fecal KIAA0247 and clinical features

\begin{tabular}{cccc}
\hline Features $^{\mathbf{a}}$ & $\boldsymbol{n}^{\mathbf{b}}$ & Kendall's tau-b & $\boldsymbol{p}$-value \\
\hline Age (years) & 55 & 0.020 & 0.836 \\
CEA $(\mathrm{ng} / \mathrm{ml})$ & 55 & -0.076 & 0.430 \\
CA19-9 $(\mathrm{U} / \mathrm{ml})$ & 53 & -0.076 & 0.440 \\
& & & \\
Tumor size $(\mathrm{cm})$ & 51 & -0.202 & 0.047 \\
\hline
\end{tabular}

a CEA, carcinoembryonic antign; CA19-9, carbohydrate antigen 19-9.

${ }^{b}$ Numbers of assessed cases are dependent on the available cases. 


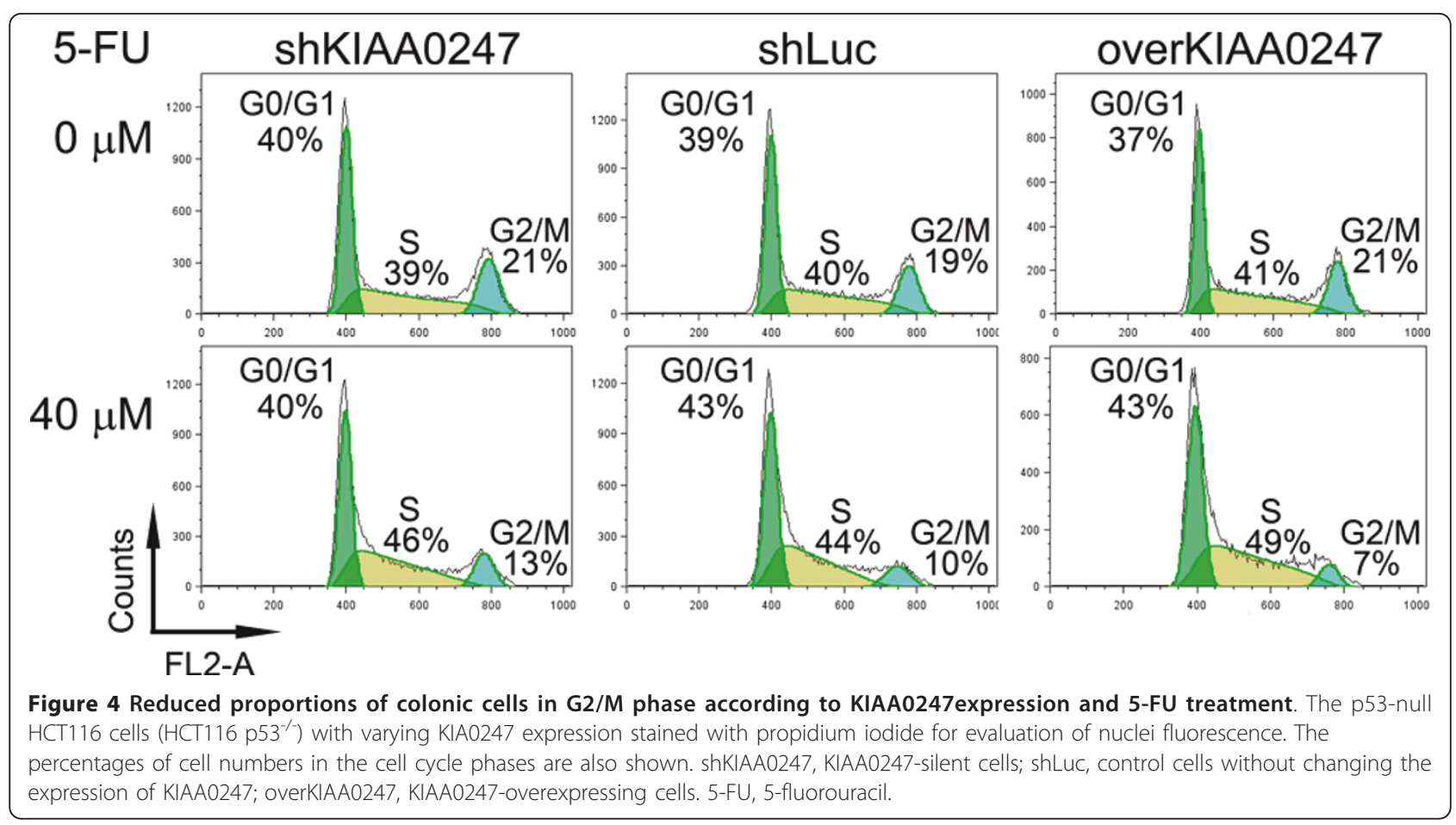

transformative stages of CRC carcinogenesis [37]. Therefore, early during CRC carcinogenesis, an effective cytotoxic effect induced by 5 -FU in the KIAA0247expressing cells could be crucial in controlling the G2/ $M$ checkpoint and in decreasing the number of cells in G2/M. At the same time, reduced levels of cyclins would negatively control the cell cycle checkpoints. The combination of cell cycle arrest and downregulation of cyclins might suggest that patients with higher fecal KIAA0247 have smaller tumors because of a slowing of

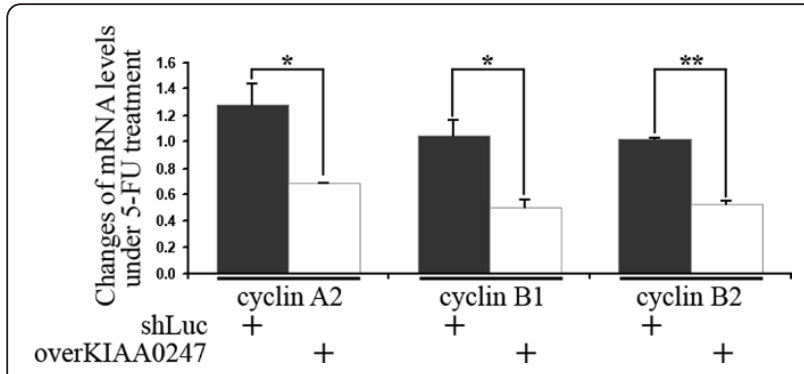

Figure 5 Cyclin gene expression changes according to KIAA0247 expression and 5-FU treatment. Individual levels of $18 \mathrm{~S}$ rRNA in the p53-null HCT116 cells (HCT116 p53/-) quantified and normalized cyclin mRNA levels. Relative expressions of cyclin genes (as indicated) acquired by comparing normalized mRNA levels of cyclins with $40 \mu \mathrm{M}$ 5-FU treatment to those in 5-FU-free conditions. shLuc, control cells without changing the expression of KIAA0247; overKIAA0247, KIAA0247-overexpressing cells. 5-FU, 5fluorouracil. The asterisks indicate ${ }^{*} p<0.05$ and ${ }^{*} p<0.01$. Data are representative of three independent experimental repeats. the progression of the cell cycle. Meanwhile, fecal KIAA0247 provides a suitable therapeutic indicator for CRC patients at Dukes' stage B in need of adjuvant 5FU therapy. This study's data are partly consistent with another group's report that enhancing the cytotoxic effect of chemotherapeutic reagents inactivates the G2/ $M$ checkpoint leading to tumor cell death [24].

When testing the cDNA from multiple tissues, KIAA0247 expression was highest in PBL and at various levels in gastrointestinal tissues. These results suggest that fecal KIAA0247 provides a more useful therapeutic reference for early-stage CRC patients than blood KIAA0247. This translocation of KIAA0247 from the cytoplasm to the nucleus might be involved in the control of the G2/M checkpoint. The cellular effect of KIAA0247 is very similar to that of $14-3-3 \sigma$, whose overexpression could also cause G2/M cell cycle arrest, although $14-3-3 \sigma$ is a p53-dependent inhibitor of G2/M progression [26].

In the group's previous studies of fecal gene expression, advanced microarray technology defined global changes in gene expression detectable in feces [18,38]. Results identified a novel gene for a homologue of the Drosophila headcase protein (HECA) as a classifier of early-stage CRC [38]. Comprehensive results for HECA and KIAA0247 indicate both fecal molecules could be markers of early-stage CRC. In this study, levels of fecal KIAA0247 inversely related to CRC tumor size with patients with high levels of fecal KIAA0247 having a longer five-year overall survival. Cell line results identifying that overexpressed KIAA0247 could move into the 


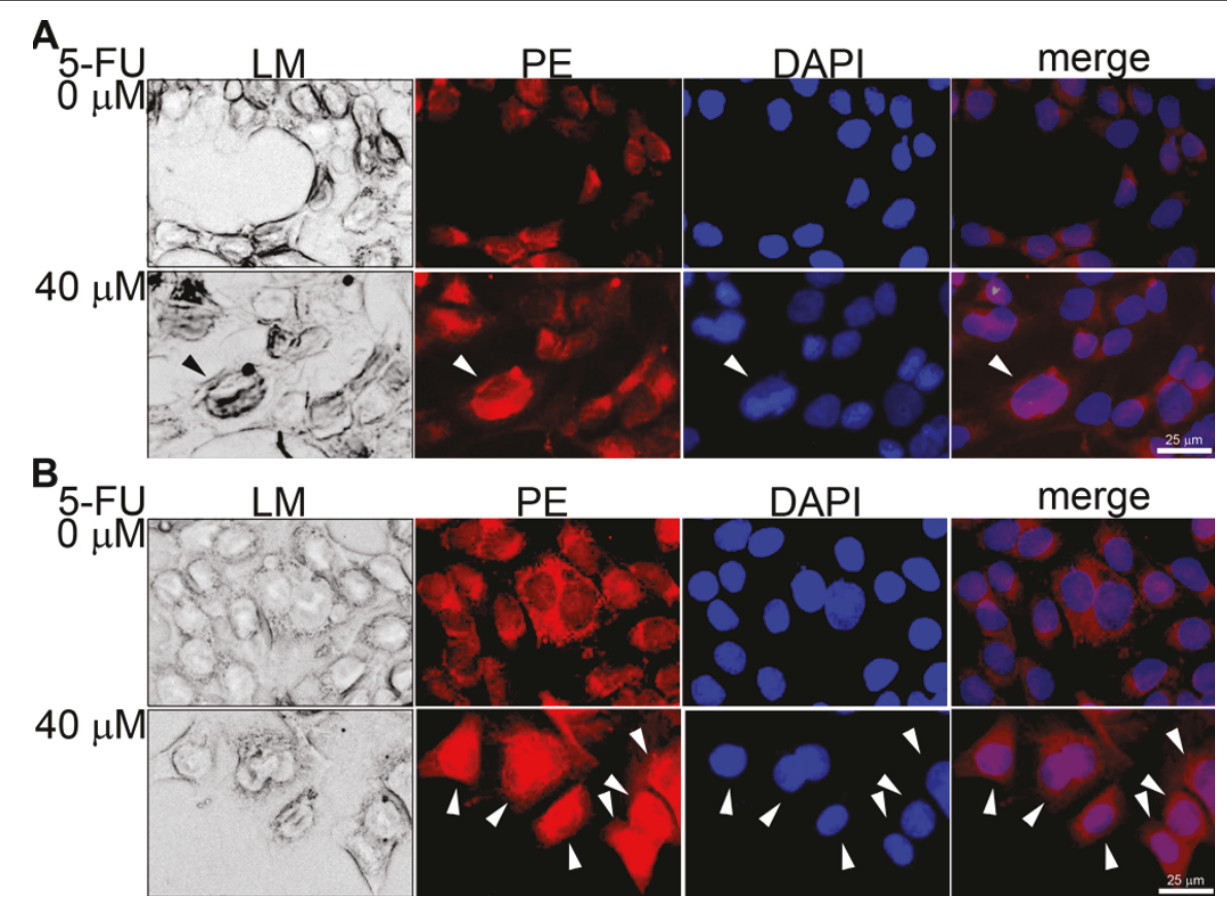

Figure 6 Changes in intracellular localization according to KIAA0247 expression and 5-FU treatment. Immunofluorescent staining in the p53-null HCT116 cells $\left(\mathrm{HCT1} 16 \mathrm{p5} 3^{-1}\right)$. A) shLuc cells $(200 \times)$ and B) overKIAA0247 cells $(200 \times)$ stained for cellular KIAA0247 using diluted antiKIAA0247 antibody. Secondary antibody, R-phycoerythrin (PE) -conjugated goat anti-rabbit antibody; DNA counterstaining, 4",6" diamidino-2phenylindole (DAPI). LM, light microscope images; Merge, merged images from PE and DAPI. White arrowhead, cells with nuclear accumulation of KIAA0247; bars, $25 \mu \mathrm{m}$.

nucleus and repress the progression of the cell cycle at the $\mathrm{G} 2 / \mathrm{M}$ phase supported the clinical findings. The downregulation of three cyclins may partly cause this repression. However, the exact mechanism by which KIAA0247 operates remains unclear. A high priority is to study other factors that lead to growth arrest, senescence, and apoptosis.

\section{Conclusions}

This study describes and characterizes, for the first time, KIAA0247 from CRC patients using flow cytometry and qRT-PCR analysis. Results indicate that fecal KIAA0247 expression is a useful indicator of the need for 5-FU treatment in CRC, especially in cases diagnosed at early stages.

\section{List of abbreviations}

CRC: colorectal cancer; 5-FU: 5-fluorouracil; qRT-PCR: quantitative real-time polymerase chain reaction; ROC: receiver-operating characteristic.

\section{Acknowledgements}

This work was supported by grants from the Cathay General Hospital and Taipei Medical University (98CGH-TMU-07 to CJH) and Taipei Veterans General Hospital (V98C1-152 to SHY). The authors would like thank the National RNAi Core Facility at the Institute of Molecular Biology/Genomic Research Center, Academia Sinica, for providing RNAi reagents, supported by the National Research Program for Genomic Medicine Grants of National Science Council (NSC 97-3112-B-001-016).

\section{Author details}

${ }^{1}$ School of Medicine, Fu Jen Catholic University, New Taipei 24205, Taiwan. 2 Department of Biochemistry, National Defense Medical Center, Taipei 11490, Taiwan. ${ }^{3}$ Department of Medical Research, Cathay General Hospital, Taipei 10630, Taiwan. ${ }^{4}$ Department of Surgery, Taipei-Veterans General Hospital and School of Medicine, National Yang Ming University, Taipei 11217, Taiwan. ${ }^{5}$ Department of Surgery, Cathay General Hospital, Taipei 10630, Taiwan.

${ }^{6}$ Department of Anesthesiology, Sijhih Cathay General Hospital, New Taipei 22174, Taiwan. ${ }^{7}$ Department of Internal Medicine, Hsinchu Cathay General Hospital, Hsinchu 30060, Taiwan. ${ }^{8}$ Division of Gastroenterology and Hepatology, Department of Internal Medicine, Taipei Medical University Hospital and Department of Internal Medicine, School of Medicine, College of Medicine, Taipei Medical University, Taipei 11031, Taiwan.

\section{Authors' contributions}

CC Chang, SHY and $\mathrm{CJH}$ participated in the design of the study and carried out the molecular analyses. YCC and HHW performed the GRT-PCR, statistical analyses, and RNAi and overexpression of target gene, flow cytometry and immuno-analyses. CML and CLL participated in discussion, and CC Chien helped in the analyses of the experiments. SHY, SMH and $\mathrm{CJH}$ worked on the manuscript, and $\mathrm{SHY}$ and $\mathrm{CJH}$ also provided grant support for this study. All authors read and approved the final version of this manuscript.

\section{Competing interests}

The authors declare that they have no competing interests.

Received: 10 February 2011 Accepted: 28 May 2011

Published: 28 May 2011

\section{References}

1. Lieberman D: Progress and challenges in colorectal cancer screening and surveillance. Gastroenterology 2010, 138:2115-2126.

2. Kim MS, Lee J, Sidransky D: DNA methylation markers in colorectal cancer. Cancer Metastasis Rev 2010, 29:181-206. 
3. Allegra C, Sargent D: Molecular diagnostics: assays, tissues, progress, and pitfalls. J Clin Oncol 2003, 21:395-396.

4. Lagerholm S, Lagerholm S, Dutta S, Nair P: Non-invasive detection of cmyc p64, c-myc p67 and c-erbb-2 in colorectal cancer. Scand J Gastroenterol 2005, 40:1343-1350.

5. Vogelstein B, Fearon ER, Hamilton SR: Genetic alterations during colorectal-tumor development. N Engl J Med 1988, 319:525-532.

6. Macarulla T, Ramos FJ, Capdevila J, Saura C, Tabernero J: Novel targets for anticancer treatment development in colorectal cancer. Clin Colorectal Cancer 2006, 6:265-272.

7. Voutsadakis IA: Pathogenesis of colorectal carcinoma and therapeutic implications: the roles of the ubiquitin-proteasome system and Cox-2. $J$ Cell Mol Med 2007, 11:252-285.

8. DiPaola RS: To arrest or not to G(2)-M Cell-cycle arrest: commentary re: A. K. Tyagi et al., Silibinin strongly synergizes human prostate carcinoma DU145 cells to doxorubicin-induced growth inhibition, G(2)-M arrest, and apoptosis. Clin. cancer res., 8: 3512-3519, 2002. Clin Cancer Res 2002, 8:3311-3314.

9. Owa T, Yoshino H, Yoshimatsu K, Nagasu T: Cell cycle regulation in the G1 phase: a promising target for the development of new chemotherapeutic anticancer agents. Curr Med Chem 2001, 8:1487-1503.

10. Carlson B, Lahusen T, Singh S, Loaiza-Perez A, Worland PJ, Pestell R, Albanese C, Sausville EA, Senderowicz AM: Down-regulation of cyclin D1 by transcriptional repression in MCF-7 human breast carcinoma cells induced by flavopiridol. Cancer Res 1999, 59:4634-4641.

11. Hirose Y, Berger MS, Pieper RO: Abrogation of the Chk1-mediated G(2) checkpoint pathway potentiates temozolomide-induced toxicity in a p53-independent manner in human glioblastoma cells. Cancer Res 2001, 61:5843-5849.

12. Robles Al, Bemmels NA, Foraker AB, Harris CC: APAF-1 is a transcriptional target of p53 in DNA damage-induced apoptosis. Cancer Res 2001, 61:6660-6664.

13. Staib F, Robles Al, Varticovski L, Wang XW, Zeeberg BR, Sirotin M, Zhurkin VB, Hofseth LJ, Hussain SP, Weinstein JN, et al: The p53 tumor suppressor network is a key responder to microenvironmental components of chronic inflammatory stress. Cancer Res 2005 65:10255-10264.

14. Kanaoka S, Yoshida K, Miura N, Sugimura H, Kajimura M: Potential usefulness of detecting cyclooxygenase 2 messenger RNA in feces for colorectal cancer screening. Gastroenterology 2004, 127:422-427.

15. Kawada M, Mizuno M, Nasu J, Uesu T, Okazaki H, Okada H, Shimomura H, Yamamoto K, Tsuji T, Fujita T, et al: Release of decay-accelerating factor into stools of patients with colorectal cancer by means of cleavage at the site of glycosylphosphatidylinositol anchor. J Lab Clin Med 2003, 142:306-312.

16. Yang SH, Chien CC, Chen CW, Li SY, Huang CJ: Potential of faecal RNA in diagnosing colorectal cancer. Cancer Lett 2005, 226:55-63.

17. Chang CC, Yang SH, Chien CC, Chen SH, Pan S, Lee CL, Lin CM, Sun HL, Huang CC, Wu YY, et al: Clinical meaning of age-related expression of fecal cytokeratin 19 in colorectal malignancy. BMC Cancer 2009, 9:376.

18. Huang CJ, Chien CC, Yang SH, Chang CC, Sun HL, Cheng YC, Liu CC, Lin SC, Lin CM: Faecal ribosomal protein L19 is a genetic prognostic factor for survival in colorectal cancer. J Cell Mol Med 2008, 12:1936-1943.

19. Yang RN, Yang SH, Chang CC, Chien CC, Pan S, Huang CJ: Upregulation of fecal cytokeratin 19 is associated with prognosis in older colorectal cancer patients. Genet Test Mol Biomarkers 2010, 14:703-708.

20. Li J, Tan J, Zhuang L, Banerjee B, Yang X, Chau JF, Lee PL, Hande MP, Li B, Yu Q: Ribosomal protein S27-like, a p53-inducible modulator of cell fate in response to genotoxic stress. Cancer Res 2007, 67:11317-11326.

21. Miyake H, Hanada N, Nakamura H, Kagawa S, Fujiwara T, Hara I, Eto H, Gohji K, Arakawa S, Kamidono S, et al: Overexpression of Bcl-2 in bladder cancer cells inhibits apoptosis induced by cisplatin and adenoviralmediated p53 gene transfer. Oncogene 1998, 16:933-943.

22. Cubas R, Zhang S, Li M, Chen C, Yao Q: Trop2 expression contributes to tumor pathogenesis by activating the ERK MAPK pathway. Mol Cancer 2010, 9:253.

23. Chang CC, Chien CC, Yang SH, Chen SH, Huang CJ: Identification and Clinical Correlation of Decreased Expression of Cytoplasmic Dynein Heavy Chain 1 in Patients with Colorectal Cancer. Clin Mol Medicine 2008, 1:6-10.
24. Fingerle-Rowson G, Petrenko O: MIF coordinates the cell cycle with DNA damage checkpoints. Lessons from knockout mouse models. Cell Div 2007, 2:22

25. Yeh YH, Huang YF, Lin TY, Shieh SY: The cell cycle checkpoint kinase CHK2 mediates DNA damage-induced stabilization of TTK/hMps1. Oncogene 2009, 28:1366-1378.

26. Taylor WR, Stark GR: Regulation of the G2/M transition by p53. Oncogene 2001, 20:1803-1815.

27. Agarwal ML, Agarwal A, Taylor WR, Stark GR: p53 controls both the G2/M and the G1 cell cycle checkpoints and mediates reversible growth arrest in human fibroblasts. Proc Natl Acad Sci USA 1995, 92:8493-8497.

28. Hermeking H, Lengauer C, Polyak K, He TC, Zhang L, Thiagalingam S, Kinzler KW, Vogelstein B: 14-3-3 sigma is a p53-regulated inhibitor of G2/ M progression. Mol Cell 1997, 1:3-11.

29. Concin N, Stimpfl M, Zeillinger C, Wolff U, Hefler L, Sedlak J, Leodolter S, Zeillinger R: Role of p53 in G2/M cell cycle arrest and apoptosis in response to gamma-irradiation in ovarian carcinoma cell lines. Int $\mathrm{J}$ Oncol 2003, 22:51-57.

30. Bache M, Dunst J, Wurl P, Frode D, Meye A, Schmidt H, Rath FW, Taubert H: G2/M checkpoint is p53-dependent and independent after irradiation in five human sarcoma cell lines. Anticancer Res 1999, 19:1827-1832

31. Chung JH, Bunz F: Cdk2 is required for p53-independent G2/M checkpoint control. PLOS Genet 2010, 6:e1000863.

32. Gangadhar T, Schilsky RL: Molecular markers to individualize adjuvant therapy for colon cancer. Nat Rev Clin Oncol 2010, 7:318-325.

33. Wang BD, Kline CL, Pastor DM, Olson TL, Frank B, Luu T, Sharma AK, Robertson G, Weirauch MT, Patierno SR, et al: Prostate apoptosis response protein 4 sensitizes human colon cancer cells to chemotherapeutic 5-FU through mediation of an NF kappaB and microRNA network. Mol Cancer 2010, 9:98.

34. Sasaki K, Tsuno NH, Sunami E, Tsurita G, Kawai K, Okaji Y, Nishikawa T, Shuno Y, Hongo K, Hiyoshi M, et al: Chloroquine potentiates the anticancer effect of 5-fluorouracil on colon cancer cells. BMC Cancer 2010, 10:370.

35. Cunningham D, Atkin W, Lenz HJ, Lynch HT, Minsky B, Nordlinger B, Starling N: Colorectal cancer. Lancet 2010, 375:1030-1047.

36. Oka K, Tanaka T, Enoki T, Yoshimura K, Ohshima M, Kubo M, Murakami T, Gondou T, Minami Y, Takemoto Y, et al: DNA damage signaling is activated during cancer progression in human colorectal carcinoma. Cancer Biol Ther 2010, 9:246-252.

37. Wei EK, Wolin KY, Colditz GA: Time course of risk factors in cancer etiology and progression. J Clin Oncol 2010, 28:4052-4057.

38. Chien CC, Chang CC, Yang SH, Chen SH, Huang CJ: A homologue of the Drosophila headcase protein, HECA, is a novel tumor marker for earlystage colorectal cancer. Oncol Rep 2006, 15:919-926.

doi:10.1186/1479-5876-9-82

Cite this article as: Huang et al:: A predicted protein, KIAA0247, is a cell cycle modulator in colorectal cancer cells under 5-FU treatment. Journal of Translational Medicine 2011 9:82.

\section{Submit your next manuscript to BioMed Central and take full advantage of:}

- Convenient online submission

- Thorough peer review

- No space constraints or color figure charges

- Immediate publication on acceptance

- Inclusion in PubMed, CAS, Scopus and Google Scholar

- Research which is freely available for redistribution

Submit your manuscript at www.biomedcentral.com/submit
C Biomed Central 